England according to a forthcoming paper by Dr. W. A. Sledge in Watsonia).

Finally, a probable Early Iron Age dating for the monoxylous 'Shapwick Boat' is based upon the pollen-analysis of a sample of peat taken from the boat, and rounds off very neatly these outstanding contributions to the history of primitive man and his environment in Somerset.

H. G. BAKER

\section{PLASTICS INDUSTRY IN SCOTLAND*}

$\mathrm{T}$ HE reconstituted Committee on Plastics appointed by the Scottish Council (Development and Industry) was appointed to inquire further into the extent to which the industry is being developed in Scotland to meet requirements, to suggest what further action is required to meet the situation, and to consider in particular the possibilities of meeting the basic requirements of the industry from raw materials in Scotland. In its final report, the Committee states that while more firms are now manufacturing finished materials from moulding powders obtained from elsewhere, and the engineering industry is in a position to tackle the highly specialized side of mould fabrication without difficulty, no developments of any kind have occurred in the manufacture of the ingredients of the moulding powders. No plastics industry can be firmly established in Scotland while these raw materials have to be imported, and the supply of coal-tar phenol and cresols is quite inadequate to meet the needs of the plastics and other industries of the United Kingdom.

The Committee recommends, therefore, that the Ministry of Supply be reminded of the urgent need for synthetic phenol, and that ample benzene and sulphuric acid are available in Scotland for the purpose. The supply of toluene is also adequate, and the sulphonation process is regarded as more attrac. tive. Royal ordnance explosives factories in the west of Scotland appear to offer the most convenient sites for the manufacture of these phenols, and the Com. mittee also recommends that the Director of Ordnance Factories should be informed accordingly. The Tar Research Association should be invited to explore methods for efficient recovery of such products as $o$-xylene and naphthalene for phthalic anhydride manufacture, and the Ministry of Supply should also be asked to consider the possibility of manufacturing methyl alcohol in Scotland as soon as the fertilizer situation is relieved.

The increasing use of plastics of the polyvinyl chloride, methacrylate and other types focuses attention on the unsaturated gases, acetylene and ethylene. The oil-refining and shale-oil industries could produce large volumes of ethylene and propylene in plant now available in Scotland, and the Com. mitte accordingly recommends that the plastics and chemical industries should be advised that adequate amounts of unsaturated gases of the required purity for the manufacture of plastics and of antiseptics, insecticides, detergents and synthetic rubbers could be made available from the petroleum-refining and shale-oil industries and from coal carbonization in Scotland. Ethylene could also be recovered from cokeoven gas without seriously affecting the calorific

Final Report of the Committee on Plastics: Plastics in Scotland. Pp. 16. (Edinburgh: Scottish Council (Development and Industry), 20 George Street, 1948.) 28. value of the gas for most industrial purposes, and the Committee recommends that the coke manufacturers be encouraged to investigate this possibility.

Since five per cent of the estimated power of the hydro-electric schemes set apart for calcium carbide manufacture would make a substantial contribution to the needs of the plasties industry in Scotland for acetylene, it is recommended finally that the Secretary of State be informed of the urgent need of an established carbide industry in Scotland for chemical as well as engineering purposes. The Committee concludes by pointing out that the rapidly increasing developments in the manufacture of flexible plastic materials emphasizes the need for a wide range of suitable plasticizers, none of which is at present made in Scotland.

The economic aspects of the whole situation are not discussed in this report; this may well draw serious criticism from the economists for neglect of an essential factor.

\section{THE NATIONAL FOUNDATION FOR ADULT EDUCATION}

$T$ HE National Foundation for Adult Education has now been constituted since January 1947 and, besides its quarterly bulletin, Foundation Papers, has published various supplements dealing with subjects of immediate importance to its corporate members.

One supplement, "Voluntary Agencies in Adult Education", contains a summary of the aims and activities of voluntary bodies working in the field of adult education. Since there is no up-to-date and comprehensive directory of adult education, the information contained in this supplement should be of particular use to local education authorities in coming to grips with the development plans for further education which they bave been asked to prepare. "Voluntary Agencies in Adult Education" will also be useful as a reference for individuals who are interested in various aspects of adult education. The supplement contains no reference to the work of university extra-mural departments and tutorial class committees, and it is intended that these should be considered in a later supplement.

The second supplement, called "Sources of Visual Aid Material : For use in the Adult Teaching of History and Contemporary Affairs", has been compiled by the deputy director, Extra-Mural Depart. ment, University of Manchester. The information has been collected partly at the request of the Associa. tion of Tutors in Adult Education and partly to meet the needs of tutors of the Manchester University Extra-Mural Department. It should also be useful to leaders of discussion groups and others concerned with adult education classes. The booklet contains a list of maps and charts, films, filmstrips, lantern slides and other pictorial material which would be suitable for adult classes of a general historical and geographical nature, and also a list of material suitable for teachers dealing with particular periods and countries.

Another supplement, "Accommodation for Adult Education : Some Examples and Suggestions", discusses an issue which presents difficulties to all the co-operating parties in adult education. A recent pamphlet of the Ministry of Education stated that : "Up and down the country there are a few colleges 